\title{
New Design of Miniature C-Band Sub- strate Integrated Waveguide Bandpass Filters Using Ceramic Material
}

\author{
Ahmed Rhbanou \\ Group MIN, ESTM \\ Superior School of Technology \\ Moulay Ismail University - Meknes \\ Morroco
}

Adiba EL Fad

High Energy Physics - Modeling and Simulation. (LPHE-MS)- Sciences Faculty, Mohamed 5 University - Rabat Morroco

Nawfal Jebbor

Full Professor

Group MIN, ESTM

Superior School of Technology

Moulay Ismail University - Meknes

Morroco

Seddik Bri

Full Professor

Group MIN, ESTM

Superior School of Technology

Moulay Ismail University - Meknes

This article presents new structures and methods of design of miniature third-order substrate integrated waveguide (SIW) bandpass filters on a high-permittivity ceramic substrate for the C-band. The aim was to appraise the feasibility of such filters by using a 3D electromagnetic (EM) simulator. The substrate integrated waveguide (SIW) offers good quality factors and electrical performances compared with other planar techniques. Its integration capabilities and fabrication cost are other benefits that make it attractive. Ceramic material offer electrical properties suitable in designing of passive devices. High relative permittivity with low dielectric losses makes it possible to miniaturize passive components while exhibiting high temperature stability, which is an important selection criterion for a filter designed to equip the payload of a satellite. Three SIW filters were designed on a Trans-Tech ceramic substrate (thickness $=254 \mu \mathrm{m}, \varepsilon_{r}=90$, and tan $\delta=0.0009$ ) with drastic specifications for space application. The first filter is composed of three SIW resonators with direct coupling, the second is composed of three SIW resonators with a cross-coupling to create a transmission zero, and the third is composed of three SIW resonators with circular holes etched on the top of the metal layer to achieve a super-wide band. The obtained results for the proposed filters are presented, discussed, and compared with relevant published literature. The proposed filter can be used to enhance the performance of microwave devices used for C-band, especially Satellite communications.

Keywords: Ceramic material, Cross-coupling, High-Permittivity, Substrate integrated waveguide (SIW), Bandpass filter

\section{INTRODUCTION}

Ceramic materials offer relevant dielectric characteristics for the conception of passive devices [1,2]. Some of them reach high relative permittivity while presenting low dielectric losses $(\tan \delta<0.001)$ [3-5]. They show themselves also very stable against temperature changes, an essential criterion for a filter used in spatial applications [6]. However, the realization of miniature filters is confronted by more restrictive technological constraints (a narrower microstrip line and finer drillings).

A substrate integrated waveguide (SIW) allows integration of the rectangular waveguide into a substrate through two arrays of via holes [7,8]. These vias must all have the same diameter and must have sufficiently small spacing to appear as perfect electric walls [9-11]. A recent work on the state-of-the-art of the SIW technology makes an inventory of the main published papers on SIW filters [12-24]. Most of the SIW filters were designed on a standard alumina substrate with excellent

Received: April 2020, Accepted: September 2020 Correspondence to: Seddik Bri, Group Material and Instrumentaions MIN, Superior Scool of Technology, Moulay Ismail University Meknes, Morocco

E-mail: seddikbri@gmail.com

doi: 10.5937/fme2101103R

(C) Faculty of Mechanical Engineering, Belgrade. All rights reserved performances of low insert loss and high $\mathrm{Q}$ factor compared with the other planar techniques. However, the dimensions of these SIW filters are so large that they are difficult to integrate in satellite payload equipment.

In this paper, we propose to design SIW filters on a high-permittivity ceramic substrate for the C-band in order to achieve drastic specifications for space application with the best compromise between size and electrical performances. We begin with the design of a third-order direct-coupled SIW filter on a standard alumina substrate (thickness $=254 \mu \mathrm{m}, \varepsilon_{\mathrm{r}}=9.9$, and $\tan \delta=0.0003$ ) and then conceive its equivalent (the same order, the same frequencies) on a Trans-Tech ceramic substrate (thickness $=254 \mu \mathrm{m}, \varepsilon_{\mathrm{r}}=90$, and $\tan \delta$ $=0.0009$ ).

The results obtained are compared in order to evaluate the performance of the high-permittivity ceramic. Then, two other third-order SIW filters are designed on a substrate with a relative permittivity of 90, the first one with a cross-coupling between resonators to create a transmission zero and the second with circular holes etched on the top of the metal layer to achieve a super-wide bandpass. Gold metal walls $(\sigma=$ $41 \times 10^{6} \mathrm{~S} / \mathrm{m}$ ) with a thickness of $4 \mu \mathrm{m}$ will be used for the metallization. The structures will be simulated by using the available Ansoft software High Frequency Structure Simulator (HFSS). 


\section{DESIGN OF THE C-BAND THIRD-ORDER DIRECT-COUPLED SIW BANDPASS FILTER}

The filter must exhibit electrical specifications of a central frequency of $5.24 \mathrm{GHz}$ with an $8 \%$ fractional bandwidth. The return loss must be better than $20 \mathrm{~dB}$ in the whole passband and the attenuation must be higher than $20 \mathrm{~dB}$ for frequencies $\geq 5.7 \mathrm{GHz}$. The coupling structure of this filter is shown in Fig. 1.

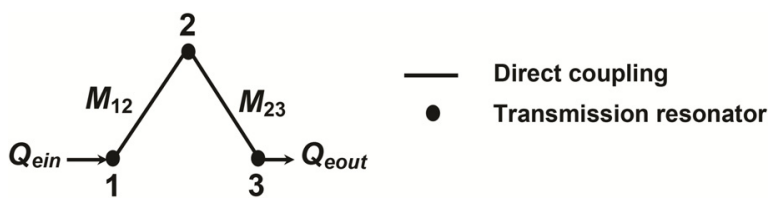

Figure 1. Coupling structure of the third-order directcoupled SIW bandpass filter.

where $\mathrm{Q}_{\text {ein }}$ and $\mathrm{Q}_{\text {eout }}$ are the external quality factors of the resonators at the input and at the output, and $\mathrm{M}_{12}$ and $\mathrm{M}_{23}$ are the coupling coefficients between the resonators. The external quality factors $\left(\mathrm{Q}_{\text {ein }}, \mathrm{Q}_{\text {eout }}\right)$ and the coupling matrix [m] of this filter are given by (1) and (2), respectively.

$$
\begin{aligned}
& Q_{\text {ein }}=Q_{\text {eout }}=10.6682 \\
& {[m]=\left[\begin{array}{ccc}
0 & 1.03027 & 0 \\
1.03027 & 0 & 1.03027 \\
0 & 1.03027 & 0
\end{array}\right]}
\end{aligned}
$$

where $\mathrm{m}_{\mathrm{ij}}$ denotes the so-called normalized coupling coefficient [25].

$$
m_{i j}=\frac{M_{i j}}{F B W} \quad \text { for } i, j=1,2, \ldots . n
$$

where $\mathrm{n}$ is the order of the filter and FBW is the designed fractional bandwidth.

\subsection{SIW filter designed on a substrate $\left(\varepsilon_{\mathrm{r}}=9.9\right)$}

The substrate used is alumina with a permittivity of 9.9, a thickness of $254 \mu \mathrm{m}$, and $\tan \delta=0.0003$. A $50-\Omega$ microstrip line designed on this substrate at a frequency of $5.24 \mathrm{GHz}$ corresponds to a width of $\mathrm{W}_{\mathrm{M}}=0.24 \mathrm{~mm}$ and therefore this access line can be realized. The impedance matching between the SIW filter and the 50- $\Omega$ lines is made by intermediate transitions between them [26-28]. The physical dimensions of these transitions control the external quality factors of the filter.

The external quality factor $Q_{e}$ can be extracted from the structure shown in Fig. 2, an SIW square cavity ( $P$, $\mathrm{D}$, and $\left.\mathrm{W}_{\mathrm{SIW} 1}=\mathrm{L}_{\mathrm{SIW} 1}\right)$ coupled to a $50-\Omega$ access line $\left(\mathrm{W}_{\mathrm{M}}\right.$ and $\left.\mathrm{L}_{\mathrm{M}}\right)$ via a microstrip transition $\left(\mathrm{W}_{\mathrm{T}}\right.$ and $\left.\mathrm{L}_{\mathrm{T}}\right)$. This structure must be well sized to have a resonance frequency of $5.24 \mathrm{GHz}$ ( $\mathrm{TE}_{101}$ mode). The dimensions are obtained by applying the equations and rules adopted in [29-33], namely $\mathrm{D}=0.2 \mathrm{~mm}, \mathrm{P}=0.5 \mathrm{~mm}$, $\mathrm{W}_{\mathrm{SIW} 1}=\mathrm{L}_{\mathrm{SIW} 1}=11.8 \mathrm{~mm}, \mathrm{~W}_{\mathrm{T}}=4.72 \mathrm{~mm}, \mathrm{~W}_{\mathrm{M}}=0.24$ $\mathrm{mm}$, and $\mathrm{L}_{\mathrm{M}}=1.2 \mathrm{~mm}$. The parameter involved in the study of this coupling is the length $\mathrm{L}_{\mathrm{T}}$ of the taperedmicrostrip transition. The value of $\mathrm{Q}_{\mathrm{e}}$ is obtained from the simulation and the use of the following equation [34, 35]:

$$
Q_{e}=\frac{f_{0}}{\Delta f_{ \pm 90^{0}}}
$$

where $\mathrm{f}_{0}$ is the resonant frequency of the SIW cavity and $\Delta \mathrm{f} \pm 90^{\circ}$ is the $\pm 90^{\circ}$ bandwidth of the SIW cavity. Fig. 3 shows the variation of $\mathrm{Q}_{\mathrm{e}}$ as a function of $\mathrm{L}_{\mathrm{T}}$.

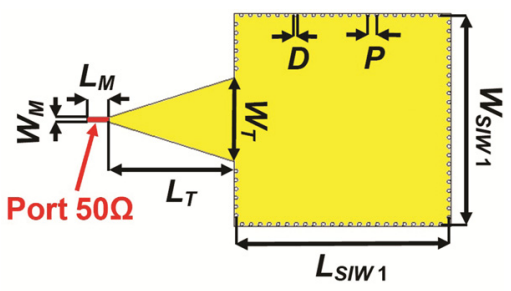

(a)

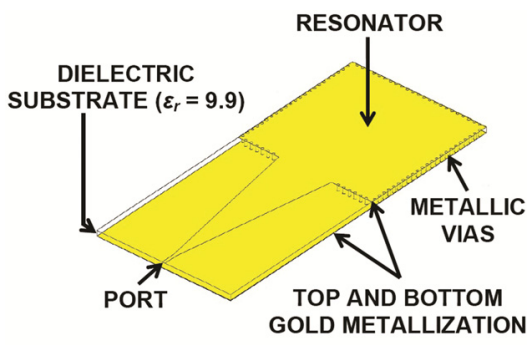

(b)

Figure 2. Arrangement for extracting the external quality factor $Q_{e}$. (a) Top view. (b) Three-dimensional (3D).

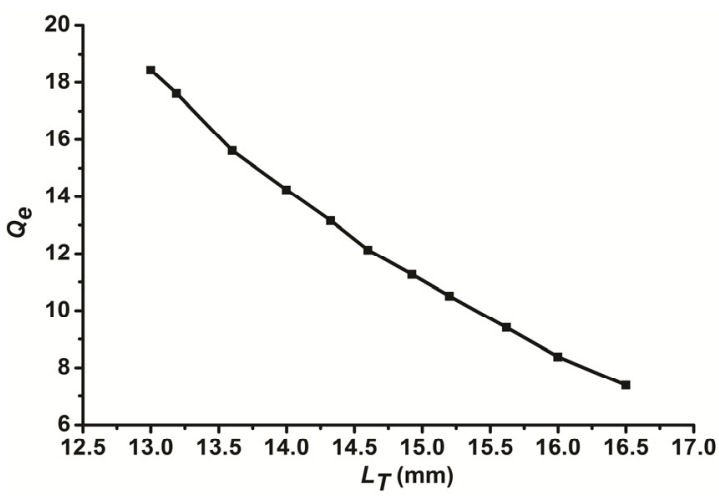

Figure 3. External coupling $Q_{e}$ as a function of parameter $L_{T}$.

We can see that the external quality factor $\mathrm{Q}_{\mathrm{e}} \mathrm{dec}$ reases when the length $\mathrm{L}_{\mathrm{T}}$ of the tapered-microstrip transition becomes larger and larger. Thus, as required for filter specifications, $Q_{\text {ein }}=Q_{\text {eout }}=10.6682$ is obtained when $\mathrm{L}_{\mathrm{T}}=15.1 \mathrm{~mm}$. The coupling coefficient $\mathrm{M}_{12}$ can be extracted from the structure shown in Fig. 4. An SIW square cavity with a resonance at $5.75 \mathrm{GHz}$ coupled to another SIW cavity with a resonance at 5.47 $\mathrm{GHz}$ via an iris opening $\mathrm{d}_{12} \cdot \mathrm{M}_{12}$ is obtained from the simulation by $[36,37]$ :

$$
M= \pm \frac{1}{2}\left(\frac{f_{02}}{f_{01}}+\frac{f_{01}}{f_{02}}\right) \sqrt{\left(\frac{f_{2}^{2}-f_{1}^{2}}{f_{2}^{2}+f_{1}^{2}}\right)^{2}-\left(\frac{f_{02}^{2}-f_{01}^{2}}{f_{02}^{2}+f_{01}^{2}}\right)^{2}}
$$

where $\mathrm{f}_{01}$ and $\mathrm{f}_{02}$ are the self-resonant frequencies of the first and second resonators, respectively, and $f_{1}$ and $f_{2}$ represent the lower and higher resonant frequencies, respectively, obtained from the EM-simulated results. Fig. 5 shows the evolution of the coupling coefficient 
$\mathrm{M}_{12}$ as a function of the iris opening $\mathrm{d}_{12}$. We can see that the increase of the iris opening produces an increase of the coupling coefficient. Thus, as required for the filter specifications, $\mathrm{M}_{12}=\mathrm{M}_{23}=0.08242$ is obtained for an iris opening equal to $7.4 \mathrm{~mm}$.

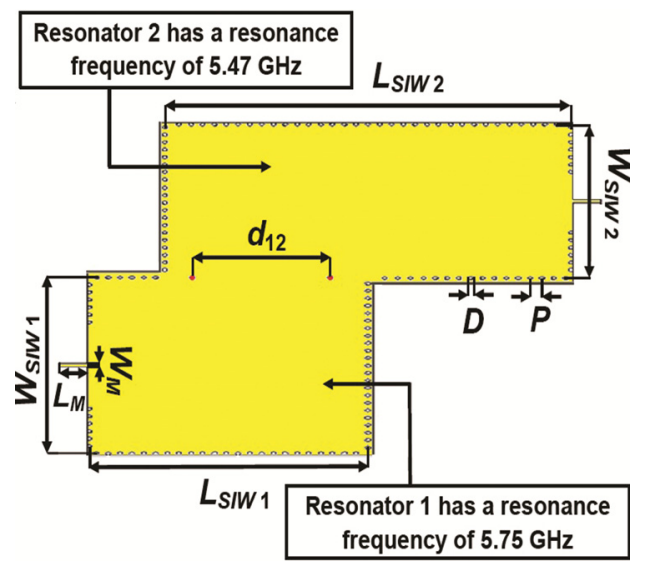

Fig. 4. Top view of arrangement for extracting coupling coefficient $M_{12}$, where $D=0.2 \mathrm{~mm}, P=0.5 \mathrm{~mm}, W_{\text {siw1 }}=L_{\text {siw1 }}$ $=11.8 \mathrm{~mm}, W_{\text {SIW } 2}=10.2 \mathrm{~mm}, L_{\text {sIW } 2}=17.2 \mathrm{~mm}, W_{M}=0.24 \mathrm{~mm}$, and $L_{M}=1.2 \mathrm{~mm}$.

The geometrical structure of the third-order directcoupled SIW band pass filter on an alumina substrate $\left(\varepsilon_{\mathrm{r}}\right.$ $=9.9$ ) is shown in Fig. 6. The dimensions of this filter are optimized by the HFSS software in order to obtain the desired frequency response (Table 1).

From the simulation results (Fig. 7 (a)), the filter has a 3-dB bandwidth of $0.41 \mathrm{GHz}$ (a fractional bandwidth of $7.8 \%$ ) and an insertion loss of $2.43 \mathrm{~dB}$ at a centre frequency of $5.24 \mathrm{GHz}$. It also has a return loss better than $18.5 \mathrm{~dB}$ from 5.02 to $5.28 \mathrm{GHz}$ and a rejection level higher than $20 \mathrm{~dB}$ from 6.05 to $6.67 \mathrm{GHz}$. We also note that the group delay of $\mathrm{S}_{21}$, shown in Fig. 7 (b), is $1.98 \mathrm{~ns}$ at $5.24 \mathrm{GHz}$ with a variation of $1.1 \mathrm{~ns}$ in the passband (from 4.98 to $5.39 \mathrm{GHz}$ ). Note that the surface area of the filter is $53.4 \mathrm{~mm} \times 22.2 \mathrm{~mm}=1185.5 \mathrm{~mm}^{2}$ (Fig. 6).

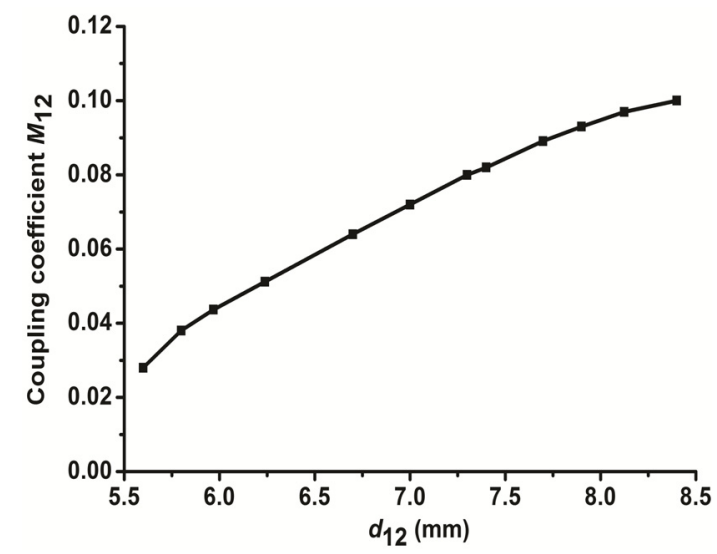

Figure 5. Coupling coefficient $M_{12}$ versus parameter $d_{12}$.

Table 1: Dimensions of the third-order direct-coupled siw bandpass filter on a standard alumina substrate

\begin{tabular}{|c|c|c|c|c|c|}
\hline Symbol & $\begin{array}{c}\text { Value } \\
(\mathrm{mm})\end{array}$ & Symbol & $\begin{array}{c}\text { Value } \\
(\mathrm{mm})\end{array}$ & Symbol & $\begin{array}{c}\text { Value } \\
(\mathrm{mm})\end{array}$ \\
\hline $\mathrm{D}$ & 0.2 & $\mathrm{~W}_{\mathrm{SIW} 2}$ & 10.2 & $\mathrm{~W}_{\mathrm{T}}$ & 4.72 \\
\hline $\mathrm{P}$ & 0.5 & $\mathrm{~L}_{\mathrm{SIW} 2}$ & 17.2 & $\mathrm{~L}_{\mathrm{T}}$ & 13.6 \\
\hline $\mathrm{W}_{\mathrm{SIW} 1}$ & 11.8 & $\mathrm{~W}_{\mathrm{M}}$ & 0.24 & $\mathrm{~d}_{12}$ & 5.6 \\
\hline $\mathrm{L}_{\mathrm{SIW} 1}$ & 11.8 & $\mathrm{~L}_{\mathrm{M}}$ & 1.2 & $\mathrm{~d}_{23}$ & 5.6 \\
\hline
\end{tabular}

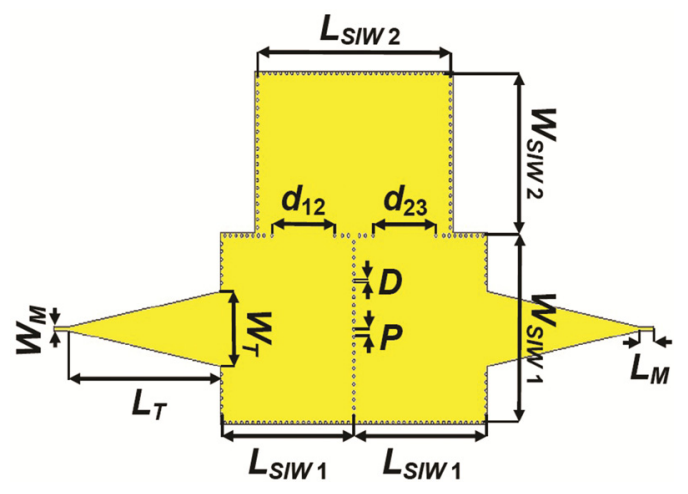

Figure 6. Top view of the third-order direct-coupled SIW bandpass filter on a standard alumina substrate $\left(\varepsilon_{\mathrm{r}}=9.9\right)$.

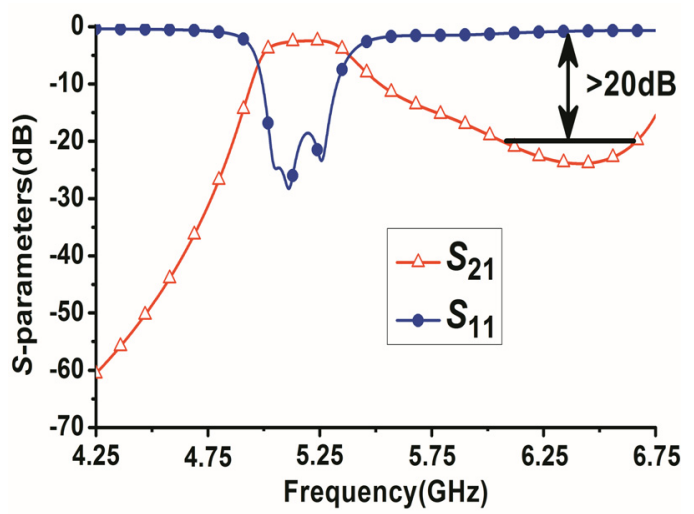

(a)

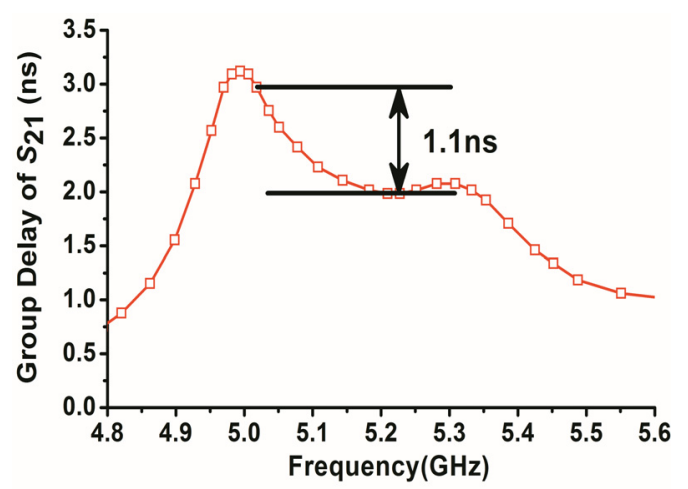

(b)

Figure 7. Simulated results of the third-order direct-coupled SIW bandpass filter on a standard alumina substrate $\left(\varepsilon_{r}=9.9\right)$. (a) S-parameters. (b) Group delay of $S_{21}$.

\subsection{SIW filter designed on a high-permittivity substrate $\left(\varepsilon_{\mathrm{r}}=90\right)$}

The third-order direct-coupled SIW bandpass filter on a high-permittivity ceramic substrate is designed by following the same process of design as for a third-order direct-coupled SIW bandpass filter on a standard alumina substrate $\left(\varepsilon_{\mathrm{r}}=9.9\right)$. The selected substrate was provided by Trans-Tech. Its relative permittivity is 90 , thickness is $254 \mu \mathrm{m}$, and the loss tangent is less than 0.0009 . The access line that we used on this substrate has a width of $\mathrm{W}_{\mathrm{M}}=0.17 \mathrm{~mm}$, which corresponds to a characteristic impedance of $20 \Omega$ at $5.24 \mathrm{GHz}$. As a result, the $50-\Omega$ lines are eliminated due to the fineness of the corresponding line width (of the order of $5.8 \mu \mathrm{m}$ ). Then, using equation (4) and the same structure as in Fig. 2 under the conditions of $\mathrm{D}=0.2 \mathrm{~mm}, \mathrm{P}=0.5 \mathrm{~mm}, \mathrm{~W}_{\mathrm{SIW} 1}$ $=\mathrm{L}_{\mathrm{SIW} 1}=4 \mathrm{~mm}, \mathrm{~W}_{\mathrm{T}}=1 \mathrm{~mm}, \mathrm{~W}_{\mathrm{M}}=0.17 \mathrm{~mm}$, and $\mathrm{L}_{\mathrm{M}}=1$ 
$\mathrm{mm}$, we are able to present the variation of $\mathrm{Q}_{\mathrm{e}}$ as a function of $\mathrm{L}_{\mathrm{T}}$ (Fig. 8). We can thus see that the external quality factor $\mathrm{Q}_{\mathrm{e}}$ obtained by the synthesis, whose value is 10.6682 , implies the use of a length of $L_{T}=1.15 \mathrm{~mm}$.

In the same way, for the coupling between the adjacent cavities $\left(\mathrm{M}_{12}=\mathrm{M}_{23}\right)$, using equation (5) and the structure of Fig. 4 under the conditions of $\mathrm{D}=0.2 \mathrm{~mm}$, $\mathrm{P}=0.5 \mathrm{~mm}, \mathrm{~W}_{\mathrm{SIW} 1}=\mathrm{L}_{\mathrm{SIW} 1}=4 \mathrm{~mm}, \mathrm{~W}_{\mathrm{SIW} 2}=3.305 \mathrm{~mm}$, $\mathrm{L}_{\mathrm{SIW} 2}=6 \mathrm{~mm}, \mathrm{~W}_{\mathrm{M}}=0.17 \mathrm{~mm}$, and $\mathrm{L}_{\mathrm{M}}=1 \mathrm{~mm}$, we obtain the variation of the coupling coefficient $\mathrm{M}_{12}$ as a function of the iris opening $d_{12}$ (Fig. 9). We can thus observe that $\mathrm{M}_{12}=\mathrm{M}_{23}=0.08242$ is obtained for an iris opening equal to $2.68 \mathrm{~mm}$.

The configuration and optimal physical dimensions of the third-order direct-coupled SIW bandpass filter on a high-permittivity ceramic substrate $\left(\varepsilon_{\mathrm{r}}=90\right)$ are shown in Fig. 10 and Table 2, respectively. We note that the surface area is $12.4 \mathrm{~mm} \times 7.675 \mathrm{~mm}=95.17 \mathrm{~mm}^{2}$, which represents a considerable miniaturization with a nearly $92 \%$ reduction in the surface area compared to the filter on an alumina substrate (Fig. 6). The results obtained with HFSS (Fig. 11) proved that the fractional bandwidth is $8 \%$ and the insertion loss is $2.66 \mathrm{~dB}$ at the centre frequency of $5.24 \mathrm{GHz}$. Thus, the return loss is better than $20 \mathrm{~dB}$ from 5.09 to $5.35 \mathrm{GHz}$, the rejection level is higher than $20 \mathrm{~dB}$ from 5.7 to $6.6 \mathrm{GHz}$, and the variation of group delay is less than $0.61 \mathrm{~ns}$ in the passband.

These results confirm that the proposed filter on a substrate with a relative permittivity of 90 (Fig. 10) satisfies the required specifications with a very significant size reduction.

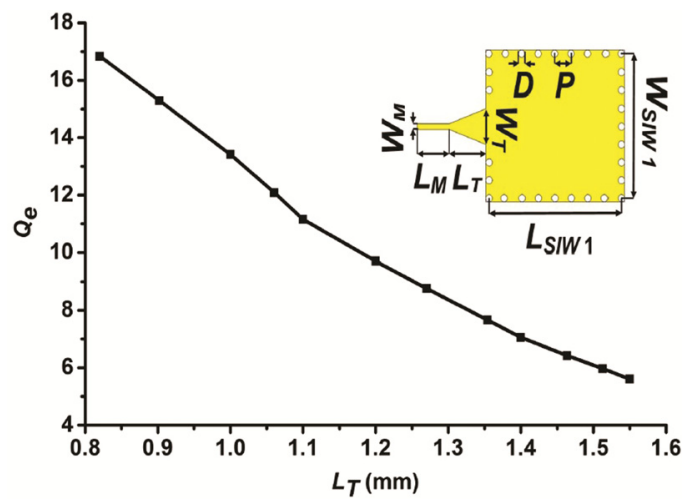

Figure 8. $Q_{e}$ as a function of $L_{T}$, where $D=0.2 \mathrm{~mm}, P=0.5$ $\mathrm{mm}, \mathrm{W}_{\mathrm{SIW} 1}=\mathrm{L}_{\mathrm{SIW} 1}=4 \mathrm{~mm}, \mathrm{~W}_{\mathrm{T}}=1 \mathrm{~mm}, \mathrm{~W}_{\mathrm{M}}=0.17 \mathrm{~mm}$, and $\mathrm{L}_{\mathrm{M}}=1 \mathrm{~mm}$.

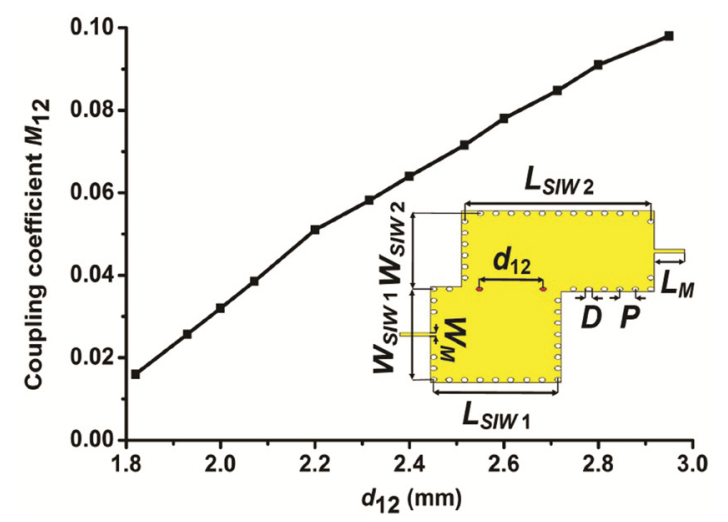

Figure 9. $M_{12}$ as a function of $d_{12}$, where $D=0.2 \mathrm{~mm}, P=0.5$ $\mathrm{mm}, W_{\mathrm{sIW} 1}=L_{\mathrm{sIW} 1}=4 \mathrm{~mm}, W_{\mathrm{sIW} 2}=3.305 \mathrm{~mm}, L_{\mathrm{sIW} 2}=6 \mathrm{~mm}$, $W_{M}=0.17 \mathrm{~mm}$, and $L_{M}=1 \mathrm{~mm}$.

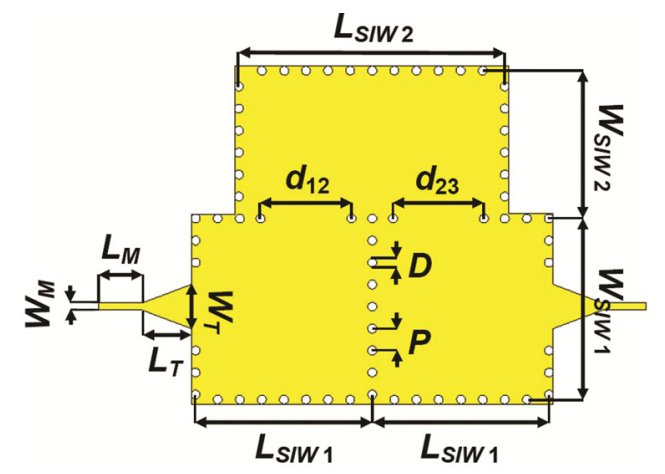

Fig. 10. Top view of the third-order direct-coupled SIW bandpass filter on a high-permittivity ceramic substrate $\left(\varepsilon_{\mathrm{r}}=90\right)$.

Table 2: Dimensions of the third-order direct-coupled SIW bandpass filter on a high-permittivity ceramic

\begin{tabular}{|c|c|c|c|c|c|}
\hline Symbol & $\begin{array}{c}\text { Value } \\
(\mathrm{mm})\end{array}$ & Symbol & $\begin{array}{c}\text { Value } \\
(\mathrm{mm})\end{array}$ & Symbol & $\begin{array}{c}\text { Value } \\
(\mathrm{mm})\end{array}$ \\
\hline $\mathrm{D}$ & 0.2 & $\mathrm{~W}_{\text {SIW2 }}$ & 3.36 & $\mathrm{~W}_{\mathrm{T}}$ & 1 \\
\hline $\mathrm{P}$ & 0.5 & $\mathrm{~L}_{\mathrm{SIW} 2}$ & 6 & $\mathrm{~L}_{\mathrm{T}}$ & 1.1 \\
\hline $\mathrm{W}_{\text {SIW1 }}$ & 4.115 & $\mathrm{~W}_{\mathrm{M}}$ & 0.17 & $\mathrm{~d}_{12}$ & 2.06 \\
\hline $\mathrm{L}_{\text {SIW1 }}$ & 4 & $\mathrm{~L}_{\mathrm{M}}$ & 1 & $\mathrm{~d}_{23}$ & 2.06 \\
\hline
\end{tabular}

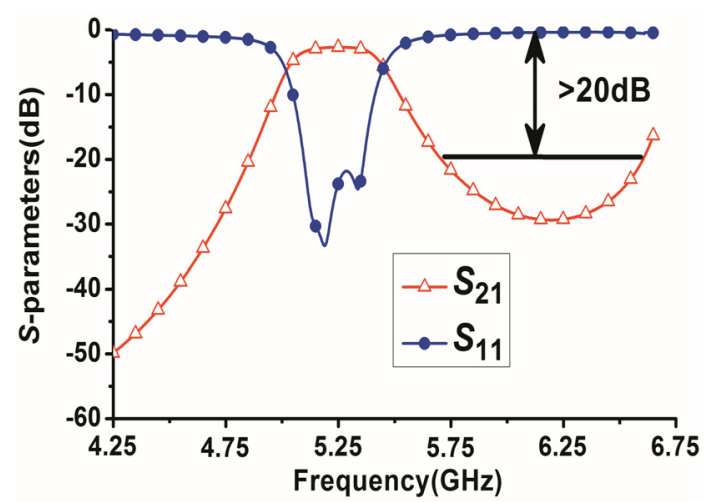

(a)

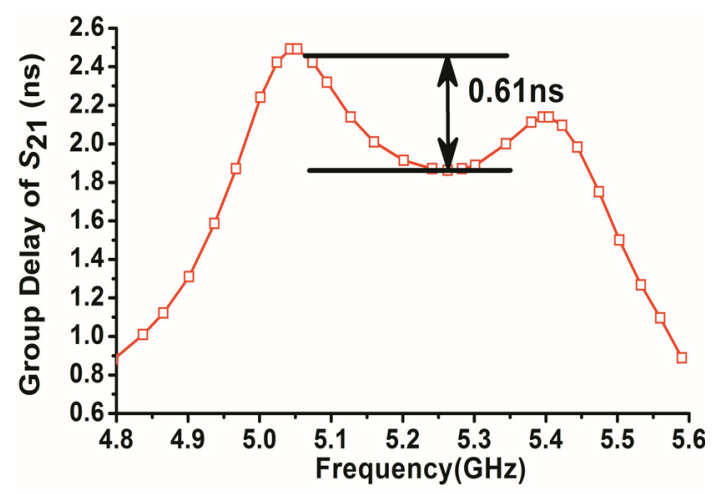

(b)

Fig. 11. Simulated results of the third-order direct-coupled SIW bandpass filter on a high-permittivity ceramic substrate $\left(\varepsilon_{r}=90\right)$. (a) $S$-parameters. (b) Group delay of $S_{21}$.

\section{DESIGN C-BAND THIRD-ORDER CROSS- COUPLED SIW BANDPASS FILTER WITH CERAMIC SUBSTRATE}

This filter must be centered at $5.24 \mathrm{GHz}$ with a fractional bandwidth of $8 \%$ and a rejection of $52 \mathrm{~dB}$ at 5.77 GHz. The substrate used is also the ceramic substrate with a relative permittivity of 90 , a thickness of $254 \mu \mathrm{m}$, and $\tan \delta=0.0009$. The coupling structure of this filter is shown in Fig. 12. 


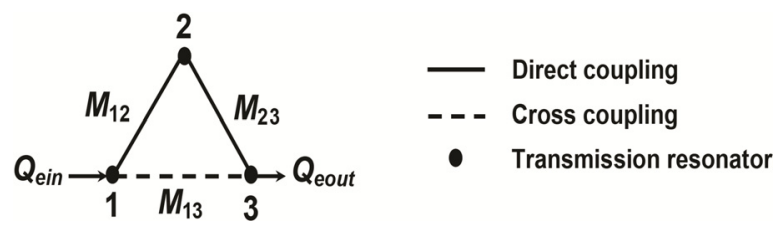

Fig. 12. Coupling structure of the third-order SIW bandpass filter with cross-coupling between resonators 1 and 3 .

The normalized coupling matrix [m] and the external quality factors $\left(\mathrm{Q}_{\mathrm{ein}}, \mathrm{Q}_{\mathrm{eout}}\right)$ of this filter are given as follows:

$$
\begin{aligned}
& {[m]=\left[\begin{array}{lrl}
0.075 & 0.99777 & 0.29859 \\
0.99777 & -0.29067 & 0.99777 \\
0.29859 & 0.99777 & 0.075
\end{array}\right]} \\
& Q_{\text {ein }}=Q_{\text {eout }}=10.6671
\end{aligned}
$$

Then, by following the same method of design as for the third-order direct-coupled SIW bandpass filter on a high-permittivity ceramic substrate (Fig. 10), we can obtain the results presented in Figs. 8 and 9. From these results, we can extract the dimensions of the coupling elements $\left(\mathrm{L}_{\mathrm{T}}, \mathrm{d}_{12}\right.$, and $\left.\mathrm{d}_{23}\right)$. Table 3 presents the coupling coefficients to be applied with their correspondence in the physical dimension.

\section{Table 3. Coupling coefficients to be applied with their} correspondence in the physical dimension

\begin{tabular}{|c|c|}
\hline $\begin{array}{c}\text { Coupling } \\
\text { Coefficients }\end{array}$ & $\begin{array}{c}\text { Dimensions of Coupling } \\
\text { Elements }(\mathrm{mm})\end{array}$ \\
\hline $\mathrm{Q}_{\mathrm{e}}=10.6671$ & $\mathrm{~L}_{\mathrm{T}}=1.15$ \\
\hline $\mathrm{M}_{12}=\mathrm{M}_{23}=0.07982$ & $\mathrm{~d}_{12}=\mathrm{d}_{23}=2.62$ \\
\hline
\end{tabular}

The cross-coupling between resonators 1 and 3 is achieved by an iris $\mathrm{d}_{13}$ (Fig. 13). The cross-coupling coefficient $\mathrm{M}_{13}$ is obtained from the simulation by [38]-[40]:

$$
M= \pm \frac{f_{2}^{2}-f_{1}^{2}}{f_{2}^{2}+f_{1}^{2}}
$$

where $f_{1}$ and $f_{2}$ also represent the lower and higher resonant frequencies, respectively, obtained from the EM-simulated results. Fig. 14 shows the evolution of the cross-coupling coefficient $\mathrm{M}_{13}$ as a function of the iris opening $\mathrm{d}_{13}$, where $\mathrm{D}=0.2 \mathrm{~mm}, \mathrm{P}=0.5 \mathrm{~mm}, \mathrm{~W}_{\text {SIW } 1}$ $=\mathrm{L}_{\mathrm{SIW} 1}=4 \mathrm{~mm}, \mathrm{~W}_{\mathrm{M}}=0.17 \mathrm{~mm}$, and $\mathrm{L}_{\mathrm{M}}=1 \mathrm{~mm}$. From this abacus, we can see that the cross-coupling coefficient $\mathrm{M}_{13}=0.02388$ is obtained for an iris opening equal to $1.5 \mathrm{~mm}$.

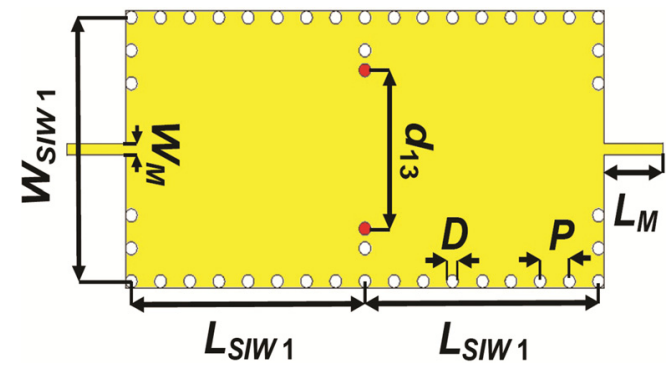

Fig. 13. Top view of arrangement for extracting the crosscoupling coefficient $\mathbf{M}_{13}$.

The geometrical structure and optimal dimensions of the third-order cross-coupled SIW bandpass filter on a high-permittivity ceramic substrate $\left(\varepsilon_{\mathrm{r}}=90\right)$ are shown in Fig. 15 and Table 4, respectively. Based to the simulated frequency response in HFSS (Fig. 16), the filter has a fractional bandwidth (FBW) of $8 \%$ and an insertion loss (IL) of $2.57 \mathrm{~dB}$ at a centre frequency (CF) of $5.24 \mathrm{GHz}$. It also has a return loss better than $20 \mathrm{~dB}$ from 5.12 to $5.4 \mathrm{GHz}$ and attenuation of $51.65 \mathrm{~dB}$ at $5.77 \mathrm{GHz}$.

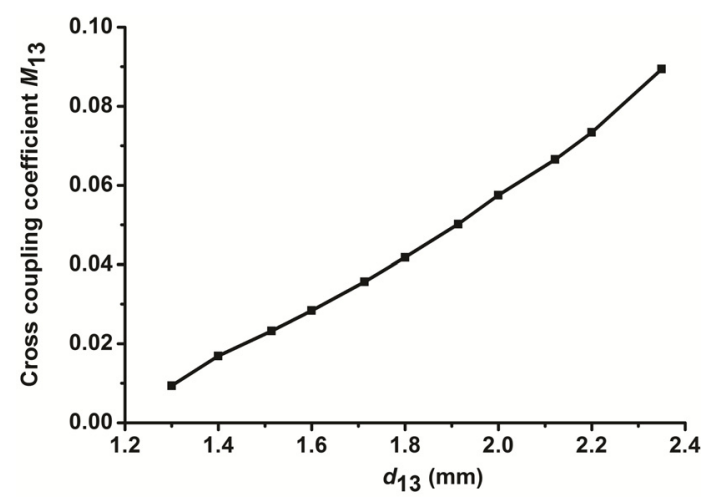

Fig. 14. Cross-coupling coefficient $M_{13}$ versus parameter $d_{13}$, where $D=0.2 \mathrm{~mm}, P=0.5 \mathrm{~mm}, W_{\mathrm{SIW} 1}=L_{\mathrm{sIw} 1}=4 \mathrm{~mm}, W_{M}$ $=0.17 \mathrm{~mm}$, and $L_{M}=1 \mathrm{~mm}$.

In order to examine the precision of the obtained results, we compared them with published results in [41]. Table 5 illustrates the comparison between the third-order cross-coupled SIW bandpass filter on a highpermittivity ceramic substrate $\left(\varepsilon_{\mathrm{r}}=90\right)$ and the filters presented in [41]. From this comparison, we have demonstrate that the proposed filter (Fig. 15) has low insertion loss, a good upper stopband ( $30 \mathrm{~dB}$ from 5.6 to $6.6 \mathrm{GHz}$ ), and a very compact size compared to the SIW filters presented in [41], which are designed on the same high-K substrate $\left(\varepsilon_{\mathrm{r}}=90\right)$. We conclude that the proposed filter (Fig. 15) has the advantage of compact size that is easy to integrate with other planar circuits and good out-band suppression with simple structure.

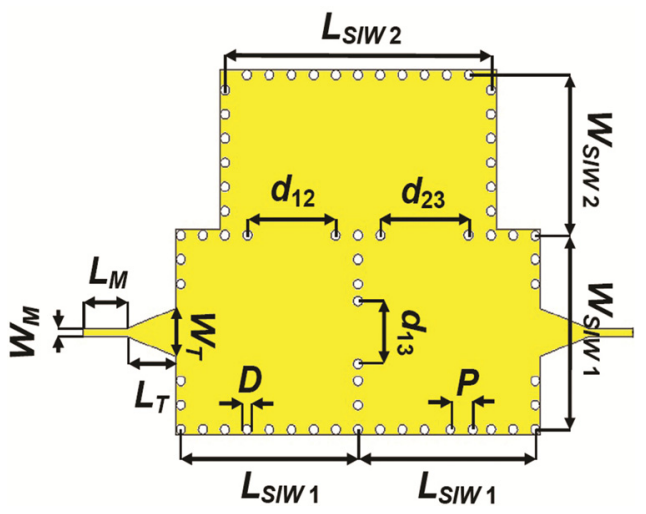

Fig. 15. Top view of the third-order cross-coupled SIW bandpass filter on a high-permittivity ceramic substrate $\left(\varepsilon_{\mathrm{r}}=90\right)$.

Table 4. Dimensions of the third-order cross-coupled SIW bandpass filter on ceramic substrate

\begin{tabular}{|c|c|c|c|c|c|}
\hline Symbol & $\begin{array}{c}\text { Value } \\
(\mathrm{mm})\end{array}$ & Symbol & $\begin{array}{c}\text { Value } \\
(\mathrm{mm})\end{array}$ & Symbol & $\begin{array}{c}\text { Value } \\
(\mathrm{mm})\end{array}$ \\
\hline $\mathrm{D}$ & 0.2 & $\mathrm{~L}_{\text {SIW2 }}$ & 6 & $\mathrm{~L}_{\mathrm{T}}$ & 1.1 \\
\hline $\mathrm{P}$ & 0.5 & $\mathrm{~W}_{\mathrm{M}}$ & 0.17 & $\mathrm{~d}_{12}$ & 1.98 \\
\hline $\begin{array}{c}\mathrm{W}_{\text {SIW1 }}= \\
\mathrm{L}_{\text {SIW1 }}\end{array}$ & 4 & $\mathrm{~L}_{\mathrm{M}}$ & 1 & $\mathrm{~d}_{23}$ & 1.98 \\
\hline $\mathrm{W}_{\text {SIW2 }}$ & 3.305 & $\mathrm{~W}_{\mathrm{T}}$ & 1 & $\mathrm{~d}_{13}$ & 1.3 \\
\hline
\end{tabular}


Table 5: Results comparison with the presented filters in [41]

\begin{tabular}{|c|c|c|c|c|c|c|c|}
\hline Ref. & Technology & Order & $\begin{array}{c}\mathrm{CF} \\
(\mathrm{GHz})\end{array}$ & $\begin{array}{c}\text { FBW } \\
(\%)\end{array}$ & IL (dB) & Upper-Band Rejection & $\begin{array}{c}\text { Size } \\
\left(\mathrm{mm}^{3}\right)\end{array}$ \\
\hline$[41]$ & $\begin{array}{c}\text { High-K Ceramic } \\
\left(\varepsilon_{\mathrm{r}}=90\right) / \mathrm{SIW}\end{array}$ & 6 & 4 & 7.2 & 2.6 & $\begin{array}{c}30 \mathrm{~dB} \\
4.25-5 \mathrm{GHz}\end{array}$ & $26.34 \times 14.24 \times 0.635$ \\
\hline$[41]$ & $\begin{array}{c}\text { High-K Ceramic } \\
\left(\varepsilon_{\mathrm{r}}=90\right) / \mathrm{SIW}\end{array}$ & 8 & 4 & 8 & 2.95 & $\begin{array}{c}30 \mathrm{~dB} \\
4.25-5 \mathrm{GHz}\end{array}$ & $33.12 \times 14.64 \times 0.635$ \\
\hline $\begin{array}{c}\text { This work } \\
\text { (Fig. 15) }\end{array}$ & $\begin{array}{c}\text { High-K Ceramic } \\
\left(\varepsilon_{\mathrm{r}}=90\right) / \mathrm{SIW}\end{array}$ & 3 & 5.24 & 8 & 2.57 & $\begin{array}{c}30 \mathrm{~dB} \\
5.6-6.6 \mathrm{GHz}\end{array}$ & $12.4 \times 7.505 \times 0.254$ \\
\hline
\end{tabular}

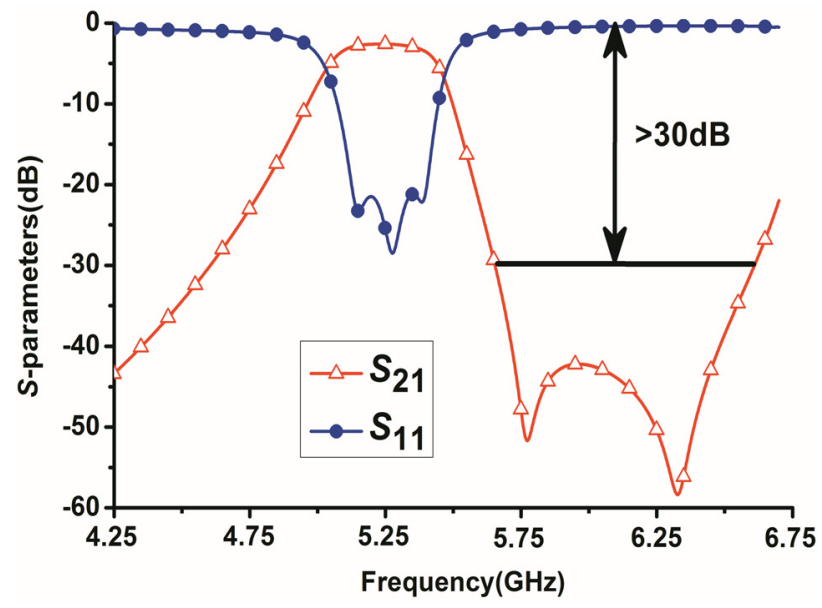

Fig. 16. Simulated frequency response of the third-order cross-coupled SIW bandpass filter on a high-permittivity ceramic substrate $\left(\varepsilon_{\mathrm{r}}=90\right)$.

\section{DESIGN C-BAND THIRD-ORDER DIRECT-COUP- LED SUPER-WIDE BANDPASS SIW FILTER WITH A CERAMIC SUBSTRATE}

This filter must exhibit performances of a centre frequency of $6.9 \mathrm{GHz}$ with a ripple of $0.1 \mathrm{~dB}$ and a fractional bandwidth of $38 \%$. The substrate used is also a ceramic substrate with a relative permittivity of 90 , a thickness of $254 \mu \mathrm{m}$, and a loss tangent of 0.0009 . The coupling structure (Fig. 17), the normalized coupling matrix $[\mathrm{m}]$, and the external quality factors $\left(\mathrm{Q}_{\text {ein }}, \mathrm{Q}_{\text {eout }}\right)$ of this filter are given below:

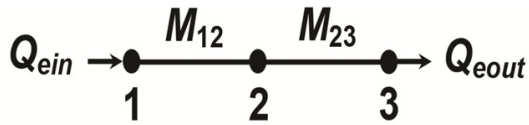

\section{- Direct coupling}

- Transmission resonator

Fig. 17. Coupling structure of the third-order direct-coupled super-wide bandpass SIW filter.

$$
\begin{aligned}
& {[m]=\left[\begin{array}{ccc}
0 & 0.9071 & 0 \\
0.9071 & 0 & 0.9071 \\
0 & 0.9071 & 0
\end{array}\right]} \\
& Q_{\text {ein }}=Q_{\text {eout }}=2.7806
\end{aligned}
$$

Fig. 18 (a) shows the structure of the SIW cavity with a circular hole etched on the top of the metal layer. The dimensions of the SIW cavity are fixed $(\mathrm{P}=0.2$ $\mathrm{mm}, \mathrm{D}=0.5 \mathrm{~mm}$, and $\left.\mathrm{W}_{\mathrm{SIW} 1}=\mathrm{L}_{\mathrm{SIW} 1}=4 \mathrm{~mm}\right)$ and therefore the resonant frequency depends only on the diameter $R_{1}$ of the circular hole. Fig. 18 (b) shows the variation of the resonant frequency as a function of $R_{1}$.
We notice that an increase in the diameter $R_{1}$ of the circular hole makes it possible to shift the resonant frequency towards a higher frequency. We can therefore reach the desired frequency $(6.9 \mathrm{GHz})$ by applying a diameter of $\mathrm{R}_{1}=1.624 \mathrm{~mm}$.

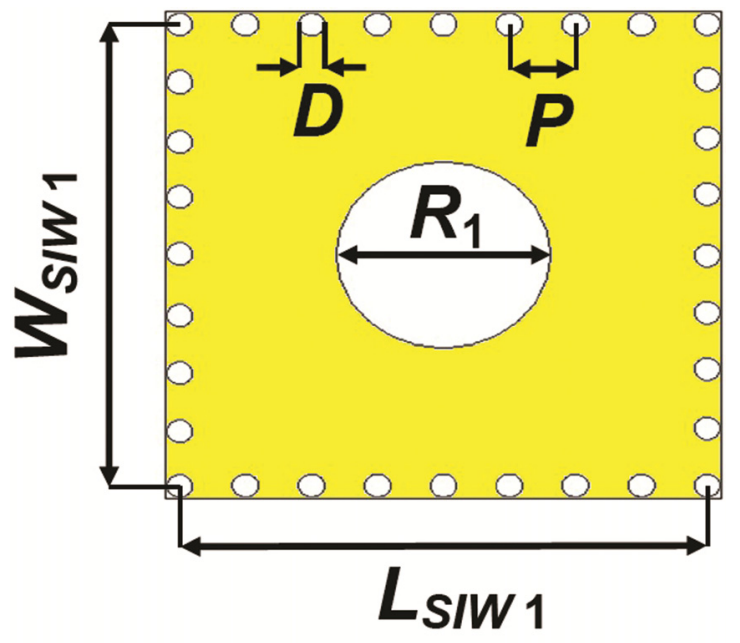

(a)

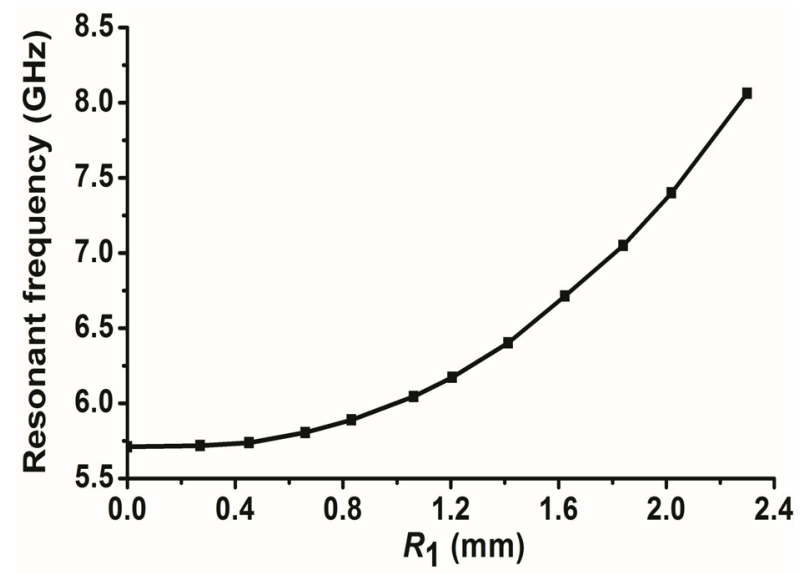

(b)

Fig. 18. (a) Top view of the SIW cavity with a circular hole etched on the top of the metal layer, where $D=0.2 \mathrm{~mm}, P=$ $0.5 \mathrm{~mm}$, and $W_{\mathrm{SIW} 1}=L_{s I W 1}=4 \mathrm{~mm}$. (b) Resonant frequency as a function of parameter $R_{1}$.

Then, using a Conductor Backed Coplanar Waveguide (CBCPW) as a transition to connect a microstrip line to an SIW square cavity with a circular hole etched on the top of the metal layer (Fig. 19 (a)), we can extract the external quality factor $\mathrm{Q}_{\mathrm{e}}$. The parameter involved in the study of $\mathrm{Q}_{\mathrm{e}}$ is the length $\mathrm{L}_{\mathrm{CPW}}$ of CBCPW transition. Fig. 19 (b) shows the variation of $\mathrm{Q}_{\mathrm{e}}$ as a function of $\mathrm{L}_{\mathrm{CPW}}$, where $\mathrm{D}=0.2 \mathrm{~mm}, \mathrm{P}=0.5$ $\mathrm{mm}, \mathrm{W}_{\mathrm{SIW} 1}=\mathrm{L}_{\mathrm{SIW} 1}=4 \mathrm{~mm}, \mathrm{R}_{1}=1.624 \mathrm{~mm}, \mathrm{~W}_{\mathrm{M}}=0.28$ $\mathrm{mm}, \mathrm{L}_{\mathrm{M}}=0.88 \mathrm{~mm}$, and $\mathrm{W}_{\mathrm{CPW}}=0.08 \mathrm{~mm}$. 


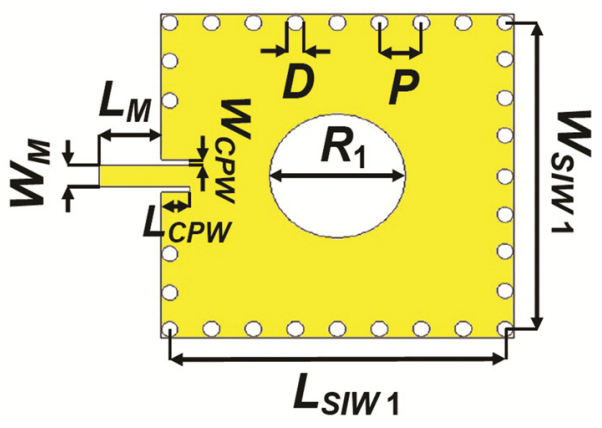

(a)

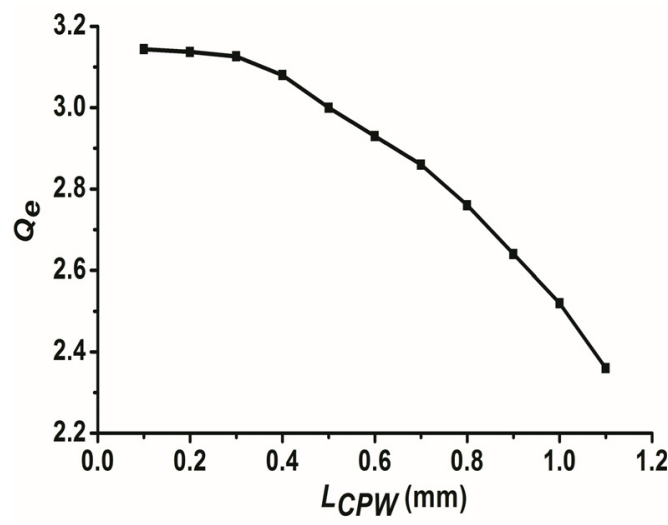

(b)

Fig. 19. (a) Top view of arrangement for extracting $Q_{e}$, where $D=0.2 \mathrm{~mm}, P=0.5 \mathrm{~mm}, W_{\mathrm{SIW}_{1}}=\mathrm{L}_{\mathrm{siw} 1}=4 \mathrm{~mm}, R_{1}=$ $1.624 \mathrm{~mm}, W_{M}=0.28 \mathrm{~mm}, L_{M}=0.88 \mathrm{~mm}$, and $W_{C P W}=0.08$ $\mathrm{mm}$. (b) $Q_{\mathrm{e}}$ as a function of $\mathrm{L}_{\mathrm{CPW}}$.

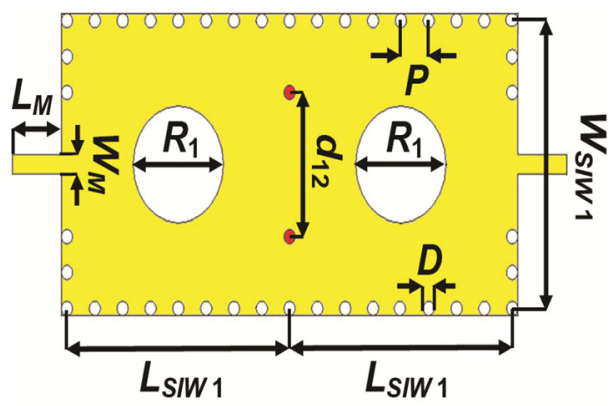

(a)

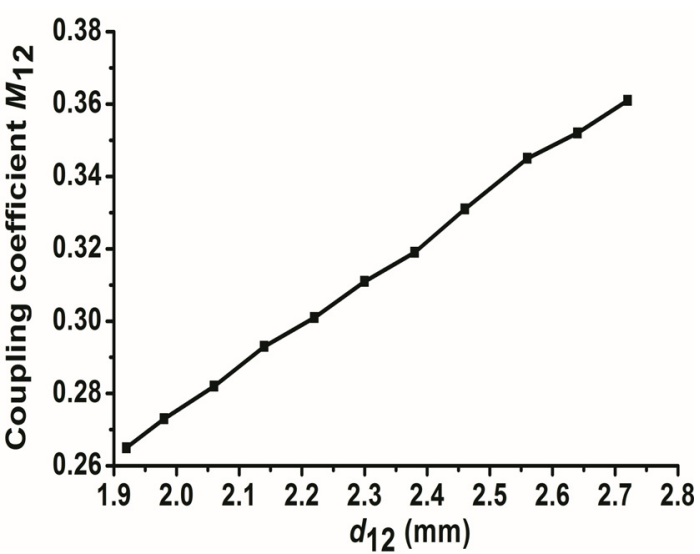

(b)

Fig. 20. (a) Top view of arrangement for extracting $M_{12}$, where $D=0.2 \mathrm{~mm}, P=0.5 \mathrm{~mm}, W_{\text {siw }_{1}}=L_{\mathrm{siw}_{1}}=4 \mathrm{~mm}, R_{1}=$ $1.624 \mathrm{~mm}, W_{M}=0.28 \mathrm{~mm}$, and $L_{M}=0.88 \mathrm{~mm}$. (b) $M 12$ as a function of d12.

For the calculation of $\mathrm{M}_{12}$, we simulate the structure of Fig. 20 (a): two resonators coupled by an iris opening. Each resonator consists of an SIW square cavity with a circular hole etched on the top of the metal layer. Then, using equation (8) for each variation of the iris opening $\mathrm{d}_{12}$ with the conditions $\mathrm{D}=0.2 \mathrm{~mm}, \mathrm{P}=0.5$ $\mathrm{mm}, \mathrm{W}_{\mathrm{SIW} 1}=\mathrm{L}_{\mathrm{SIW} 1}=4 \mathrm{~mm}, \mathrm{R}_{1}=1.624 \mathrm{~mm}, \mathrm{~W}_{\mathrm{M}}=0.28$ $\mathrm{mm}$, and $\mathrm{L}_{\mathrm{M}}=0.88 \mathrm{~mm}$, we can present the evolution of $\mathrm{M}_{12}$ as a function of $\mathrm{d}_{12}$ (Fig. 20 (b)).

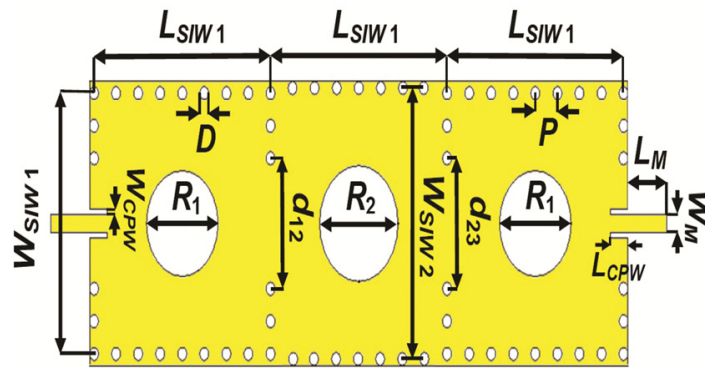

Fig. 21. Top view of the third-order direct-coupled superwide bandpass SIW filter with a high-permittivity ceramic substrate $\left(\varepsilon_{\mathrm{r}}=90\right)$ and circular holes etched on the top of the metal layer.

The results presented in Fig. 19 (b) and Fig. 20 (b) make it possible to deduce the initial dimensions to be applied for the coupling elements $\left(\mathrm{L}_{\mathrm{CPW}}\right.$ and $\left.\mathrm{d}_{12}=\mathrm{d}_{23}\right)$. The configuration and the dimensions of the filter, after optimization by HFSS, are shown in Fig. 21 and Table 6 , respectively.

The simulated frequency response by HFSS (Fig. 22) shows that the fractional bandwidth (FBW) is $38 \%$ at the centre frequency $(\mathrm{CF})$ of $6.9 \mathrm{GHz}$ and the return loss is better than $16 \mathrm{~dB}$ from 5.72 to $8.22 \mathrm{GHz}$. Thus, the minimum insertion loss (IL) is $1.26 \mathrm{~dB}$ and the ripple in the pass band is less than $0.18 \mathrm{~dB}$. Compared with the filters using high-K ceramic [42], [43] as list in Table 7, it can clearly be seen that the proposed filter (Fig. 21) has better performances, including very low ripple, lower insertion loss und greater fractional bandwidth. Also, the proposed design gets a more compact circuit size than other designs.

Table 6: Dimensions of the proposed filter (Fig. 21)

\begin{tabular}{|c|c|c|c|c|c|}
\hline Symbol & $\begin{array}{c}\text { Value } \\
(\mathrm{mm})\end{array}$ & Symbol & $\begin{array}{c}\text { Value } \\
(\mathrm{mm})\end{array}$ & Symbol & $\begin{array}{c}\text { Value } \\
(\mathrm{mm})\end{array}$ \\
\hline $\mathrm{D}$ & 0.2 & $\mathrm{~W}_{\mathrm{CPW}}$ & 0.08 & $\mathrm{~d}_{12}$ & 2 \\
\hline $\mathrm{P}$ & 0.5 & $\mathrm{~L}_{\mathrm{CPW}}$ & 0.4 & $\mathrm{~d}_{23}$ & 2 \\
\hline $\begin{array}{c}\mathrm{W}_{\text {SIW1 }}= \\
\mathrm{L}_{\text {SIW1 }}\end{array}$ & 4 & $\mathrm{~W}_{\mathrm{M}}$ & 0.28 & $\mathrm{R}_{1}$ & 1.624 \\
\hline $\mathrm{W}_{\text {SIW2 }}$ & 4.16 & $\mathrm{~L}_{\mathrm{M}}$ & 0.88 & $\mathrm{R}_{2}$ & 1.78 \\
\hline
\end{tabular}

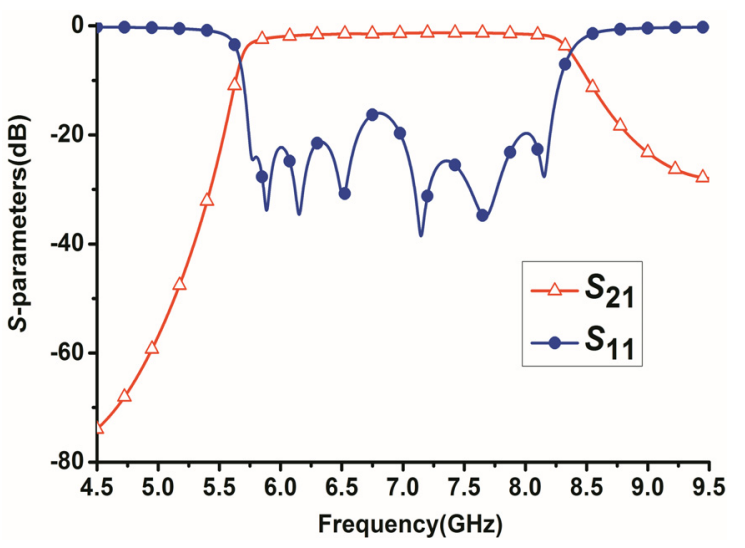

Fig. 22. Frequency response of the third-order direct-coupled super-wide band pass SIW filter with a high-permittivity ceramic substrate $\left(\varepsilon_{\mathrm{r}}=90\right)$ and circular holes etched on the top of the metal layer. 
Table 7: Comparison with the published filters

\begin{tabular}{|c|c|c|c|c|c|c|c|}
\hline Ref. & Technology & Order & $\begin{array}{c}\text { CF } \\
(\mathrm{GHz})\end{array}$ & FBW (\%) & IL (dB) & $\begin{array}{c}\text { Ripple } \\
(\mathrm{dB})\end{array}$ & $\begin{array}{c}\text { Surface } \\
\left(\mathrm{mm}^{2}\right)\end{array}$ \\
\hline$[42]$ & $\begin{array}{c}\text { High-K Ceramic } \\
\left(\varepsilon_{\mathrm{r}}=68.7\right) / \text { LTCC/SIW }\end{array}$ & 6 & 7.33 & 5 & 3.9 & 2.1 & $16.375 \times 4.3$ \\
\hline$[43]$ & $\begin{array}{c}\text { High-K } \\
\text { Ceramic }\left(\varepsilon_{\mathrm{r}}=90\right) / \\
\text { Microstrip }\end{array}$ & 5 & 3.83 & 23 & 1.12 & 1.27 & $13.51 \times 6.75$ \\
\hline $\begin{array}{c}\text { This work } \\
\text { (Fig. } 21)\end{array}$ & $\begin{array}{c}\text { High-K } \\
\text { Ceramic }\left(\varepsilon_{\mathrm{r}}=90\right) / \mathrm{SIW}\end{array}$ & 3 & 6.9 & 38 & 1.26 & 0.18 & $13.96 \times 4.36$ \\
\hline
\end{tabular}

\section{CONCLUSION}

New miniature third-order SIW bandpass filters on a high-permittivity ceramic substrate for the C-band are presented in this article. The use of a ceramic substrate with a relative permittivity of 90 allowed us to reduce the surface area of the SIW filter by nearly $92 \%$ compared to the SIW filter on alumina substrate $\left(\varepsilon_{\mathrm{r}}=9.9\right)$. The simulations results also demonstrate that this reduction in size does not influence the performances of the filter, that is to say without strong degradation of the insertion losses, and from here we conclude that such particularly high-permittivity ceramics are very attractive for frequency applications between UHF and C-band. We have also proved that the use of a cross-coupling between the resonators allows improvement of the rejection. Then, we have proposed a novel miniature $\mathrm{C}$-band super-wide bandpass SIW filter by using a high-permittivity ceramic substrate and circular holes etched on the top of the metal layer. The simulation results of the proposed filters are encouraging and filled the design criteria for radio frequency (RF) such as low insertion losses, ease of fabrication, and integration with other RF circuits in communications systems. The solution proposed in this research work is based on a ceramic substrate with a permittivity of 90 , which allowed us to reduce size and make SIW even more attractive. This confirms the feasibility of a SIW solution with a high-permittivity ceramic substrate for the design of filters intended to equip the payload of a satellite. Since C-band is mostly used for satellite and Radar applications. So, proposed SIW filter may be a good candidate to enhance the performance of Satellite application devices.

Futures works will be interesting in SIW for coupled interlinked split ring resonator based epsilon negative metamaterial with high effective medium ratio for multiband satellite and radar communications.

\section{REFERENCES}

[1] T. Zhu, J. Hu, Y. Guo, "Ka-band coplanar waveguide delay line using $\mathrm{Al}_{2} \mathrm{O}_{3}$ ceramic substrate," In: Proc. IEEE Int. Conf. Communication ProblemSolving (ICCP), Guilin, pp. 226-229, 2015.

[2] J. L. G. Medeiros, A. G. d'Assunção and L. M. Mendonça, "Microstrip fractal patch antennas using high permittivity ceramic substrate," In: Proc. IEEE Antennas and Propagation Society Int. Symp. (APSURSI), Chicago, pp. 1-2, 2012.

[3] Dinulović, M., Rašuo, B.: Dielectric properties modeling of composite materials, FME Transactions, Vol. 37 No 3, pp. 117-122, 2009.
[4] Dinulović, M., Rašuo, B., Dielectric modeling of multiphase composites, Composite Structures, Vol. 93, Issue 12, pp. 3209-3215, November 2011.

[5] Elboubakraoui, M. C., Bri, S., Foshi, J.: Dielectric Properties of $\mathrm{SiCf} / \mathrm{SiC}$ Composites, FME Transactions, Vol. 46 No 1, pp. 86-92, 2018.

[6] Y. Clavet, A. Manchec, J. F. Favennec, E. Rius, C. Quendo, B. Bonnet, J. C. Azzara, C. Debarge and J. L. Cazaux, "Design of high-permittivity ceramic UHF microstrip filter for a space application," In: Proc. Asia Pacific Microwave Conf., Singapore, pp. 2160-2163, 2009.

[7] K. Nouri, K. Haddadi, O. Benzaïm, T. Lasri and M. Feham, "Substrate integrated waveguide (SIW) inductive window band-pass filter based on postwall irises," Eur. Phys. J. Appl. Phys., vol. 53, no. 3, pp. 1-5, 2011.

[8] B. Liu, J. Zhou, R. Liu, Q. Wu and K. Zhang, "A $35 \mathrm{GHz}$ reduced-size bandpass filter based on SIW in LTCC technology," In: Proc. IEEE Int. Conf. Microwave Technology and Computational Electromagnetics (ICMTCE), Qingdao, pp. 77-80, 2013.

[9] Y. Huang, Z. Shao, L. Liu, “A substrate integrated waveguide bandpass filter using novel defected ground structure shape," Prog. Electromagn. Res., vol. 135, pp. 201-213, 2013.

[10] S. Moitra, P. S. Bhowmik, "Modelling and analysis of substrate integrated waveguide (SIW) and halfmode SIW (HMSIW) band-pass filter using reactive longitudinal periodic structures," Int. J. Electron. Commun., vol. 70, no. 12, pp. 1593-1600, 2016.

[11]D. Zelenchuk, V. Fusco, "Low insertion loss substrate integrated waveguide quasi-elliptic filters for V-band wireless personal area network applications," IET Microw. Antennas Propag., vol. 5, no. 8, pp. 921-927, 2011.

[12] R. S. Chen, S. W. Wong, L. Zhu, Q. X. Chu, "Wideband bandpass filter using U-slotted substrate integrated waveguide (SIW) cavities," IEEE Microw. Wireless Compon. Lett., vol. 25, no. 1, pp. 1-3, 2015.

[13]D. L. Diedhiou, E. Rius, J. F. Favennec, A. El Mostrah, "Ku-band cross-coupled ceramic SIW filter using a novel electric cross-coupling," IEEE Microw. Wireless Compon. Lett., vol. 25, no. 2, pp. 109-111, 2015.

[14]Z. Yang, Z. Wang, J. Dong, Y. Liu and T. Yang, "Compact wideband HMSIW bandpass filter with defected ground structure," In: Proc. IEEE Int. Conf. Signal Processing, Communications and Computing (ICSPCC), Ningbo, pp. 1-4, 2015. 
[15] L. Huang, W. Wu, X. Zhang, H. Lu, Y. Zhou and N. Yuan, "A novel compact and high performance bandpass filter based on SIW and CMRC technique," Int. J. Electron. Commun., vol. 82, pp. 420-425, 2017.

[16] Z. Xiangjun, M. Caoyuan, C. Deqiang, "Compact dual-passband LTCC filter exploiting eighth-mode SIW and SIW hybrid with coplanar waveguide," Electron. Lett., vol. 50, no. 24, pp. 1849-1851, 2014.

[17] K. Zhou, W. Kang and W. Wu, "A compact SIW balanced bandpass filter with high selectivity and good common-mode suppression," In: Proc. IEEE Int. Conf. Microwave and Millimeter Wave Technology (ICMMT), Beijing, pp. 76-78, 2016.

[18]Z. G. Wang, X. Q. Li, S. P. Zhou, B. Yan, R. M. $\mathrm{Xu}$ and W. G. Lin, "Half mode substrate integrated folded waveguide (HMSIFW) and partial H-plane bandpass filter," Prog. Electromagn. Res., vol. 101, pp. 203-216, 2010.

[19] B. Zheng, Z. Zhao and Y. Lv, “A K-band SIW filter with bypass coupling substrate integrated circular cavity (SICC) to improved stopband performance for satellite communication," Prog. Electromagn. Res. C, vol. 17, pp. 95-104, 2010.

[20] D. Li, C. Tong, J. Bao, P. Peng, D. Yu, “A novel bandpass filter of substrate integrated waveguide (SIW) based on S-shaped EBG," Prog. Electromagn. Res. Lett., vol. 36, pp. 191-200, 2013.

[21] L. N. Chen, Y. C. Jiao, Z. Zhang, F. S. Zhang and Y. Y. Chen, "Miniaturized dual-mode substrate integrated waveguide (SIW) band-pass filters loaded by double/single T-shaped structures," Prog. Electromagn. Res. Lett., vol. 29, pp. 65-74, 2012.

[22] M. Zhou, M. X. Yu, J. Xu, X. C. Zhang and M. Y. Wang, "Compact half-mode substrate integrated waveguide (HMSIW) filter with dual-mode microstrip resonator," Prog. Electromagn. Res. C, vol. 33, pp. 29-41, 2012.

[23] M. Khalil, M. Kamarei, J. Jomaah and H. Ayad, "Compact multi-layer band-pass filter in substrate integrated waveguide (SIW) technology," In: Proc. IEEE Middle East Conf. Antennas and Propagation (MECAP), Beirut, pp. 1-4, 2016.

[24] P. J. Zhang and M. Q. Li, "Cascaded trisection substrate-integrated waveguide filter with high selectivity," Electron. Lett., vol. 50, no. 23, pp. 1717-1719, 2014.

[25] J. S. Hong, "Microstrip Filters for RF/Microwave Applications, second edition," Hoboken, New Jersey: Wiley, 2011.

[26] A. Rhbanou, S. Bri, "Design of substrate integrated waveguide pass filter at [33-75] GHz band," Int. J. Eng. Technol., vol. 6, no. 6, pp. 2815-2825, 2014.

[27] O. B. Kobe, J. Chuma, Jr., R. Jamisola and M. Chose, "A review on quality factor enhanced onchip microwave planar resonators," Eng. Sci. Tech., Int. J., vol. 20, no. 2, pp. 460-466, 2017.

[28] A. Rhbanou, S. Bri and M. Sabbane, "Design of substrate integrated waveguide band pass filter based on CSRR-EBG," Int. J. Microw. Opt. Technol., vol. 11, no. 1, pp. 7-14, 2016.

[29] F. Grine, M. T. Benhabiles and M. L. Riabi, "Kuband transition with not metalized air-vias between microstrip line and substrate integrated waveguide," J. Microw. Optoelectron. Electromagn. Appl., vol. 16, no. 1, pp. 50-58, 2017.

[30]D. Deslandes, "Design equations for tapered microstrip-to-substrate integrated waveguide transitions," In: Proc. IEEE MTT-S Int. Microwave Symp. Dig. (MTT), Anaheim, pp. 704-707, 2010.

[31] A. Rhbanou, S. Bri, M. Sabbane, "Design of Xband substrate integrated waveguide bandpass filter with dual high rejection," Microw. Opt. Technol. Lett., vol. 57, no. 7, pp. 1744-1752, 2015.

[32] A. Rhbanou, S. Bri, M. Sabbane, "Design of K-band substrate integrated waveguide band-pass filter with high rejection," J. Microw. Optoelectron. Electromagn. Appl., vol. 14, no. 2, pp. 155-169, 2015.

[33] A. Rhbanou, S. Bri and M. Sabbane, "Design of substrate integrated waveguide cavity bandpass filters," In: Proc. 5th Int. Conf. Multimedia Computing and Systems (ICMCS), Marrakech, pp. 410-415, 2016.

[34] O. A. Nova, J. C. Bohorquez, N. M. Pena, G. E. Bridges, L. Shafai and C. Shafai, "Filter-antenna module using substrate integrated waveguide cavities," IEEE Antennas Wireless Propag. Lett., vol. 10, pp. 59-62, 2011.

[35] W. Shen, W. Y. Yin, X. W. Sun and L. S. Wu, "Substrate-integrated waveguide bandpass filters with planar resonators for system-on-package," IEEE Trans. Compon. Packag. Manuf. Technol., vol. 3, no. 2, pp. 253-261, 2013.

[36] A. O. Nwajana and K. S. K. Yeo, "Multi-coupled resonator microwave diplexer with high isolation," In: Proc. 46th Eur. Microwave Conf. (EuMC), London, pp. 1167-1170, 2016.

[37] V. Sekar, K. Entesari, "A novel compact dual-band half-mode substrate integrated waveguide bandpass filter," In: Proc. IEEE MTT-S Int. Microwave Symp. Dig. (MTT), Baltimore, pp. 1-4, 2011.

[38] A. Rhbanou, S. Bri, M. Sabbane, "Analysis of substrate integrated waveguide (SIW) resonator and design of miniaturized SIW bandpass filter," Int. J. Electron. Telecommun., vol. 63, no. 3, pp. 255-260, 2017.

[39]H. Cao, S. He, H. Li and S. Yang, "A compact wideband bandpass filter using novel CSRR loaded QMSIW resonator with high selectivity," Prog. Electromagn. Res. C, vol. 41, pp. 239-254, 2013.

[40]Z. Wang, S. Bu and Z. Luo, "A KA-band thirdorder cross-coupled substrate integrated waveguide bandpass filter base on 3D LTCC," Prog. Electromagn. Res. C, vol. 17, pp. 173-180, 2010.

[41] M. L. Coq, E. Rius, J. F. Favennec, C. Quendo, B. Potelon, L. Estagerie, P. Moroni, B. Bonnet and A. El Mostrah, "Miniaturized C-band SIW filters using high-permittivity ceramic substrates," IEEE Trans. Compon. Packag. Manuf. Technol., vol. 5, no. 5, pp. 620-626, 2015.

[42] J. Garreau, B. Potelon, E. Rius, J. F. Favennec, C. Quendo, C. Caille, H. Leblond, J. C. Azzara and L. Raynaud, "Ultra-compact X-band SIW filter in LTCC technology using high permittivity substrate for a space application," In: Proc. IEEE MTT-S Int. Microwave Symp. Dig. (MTT), Montreal, pp. 1-3, 2012. 
[43] M. L. Coq, E. Rius, C. Quendo, B. Potelon, J. F. Favennec, L. Estagerie, P. Moroni, Y. Clavet and A. Manchec, "Miniature microstrip filter using high-permittivity ceramic substrates $\left(\varepsilon_{\mathrm{r}}=90\right)$," In: Proc. IEEE MTT-S Int. Microwave Symp. Dig. (MTT), Baltimore, pp. 1-4, 2011.

\section{NOMENCLATURE}

\begin{tabular}{|c|c|}
\hline$Q_{\text {ein }}$ & $\begin{array}{l}\text { External quality factors of the resonators at } \\
\text { the input }\end{array}$ \\
\hline$Q_{\text {eout }}$ & $\begin{array}{l}\text { External quality factors of the resonators at } \\
\text { the output }\end{array}$ \\
\hline$M_{\mathrm{i}, \mathrm{j}}$ & $\begin{array}{l}\text { Coupling coefficient between the resonators } \\
\mathrm{i} \text { and } \mathrm{j} \text { for } \mathrm{i}, \mathrm{j}=1,2,3, . ., \mathrm{n}\end{array}$ \\
\hline$m_{\mathrm{i}, \mathrm{j}}$ & $\begin{array}{l}\text { So-called normalized coupling coefficient } \\
\text { for } \mathrm{i}, \mathrm{j}=1,2,3, . ., \mathrm{n}\end{array}$ \\
\hline$n$ & $\begin{array}{l}\text { Number of the resonators or the order of the } \\
\text { filter }\end{array}$ \\
\hline$F B W$ & Designed fractional bandwidth \\
\hline$W_{\mathrm{M}}$ & Width of the conductor \\
\hline$L_{\mathrm{M}}$ & Length of the conductor \\
\hline$Q_{\mathrm{e}}$ & External quality factor \\
\hline$P$ & Distance between the holes \\
\hline$D$ & Diameter of the metallic via \\
\hline$W_{\mathrm{SIW}}$ & Width of the SIW cavity \\
\hline$L_{\text {SIW }}$ & Length of the SIW cavity \\
\hline$W_{\mathrm{T}}$ & Width of the transition \\
\hline$L_{\mathrm{T}}$ & Length of the transition \\
\hline$f_{0}$ & Resonant frequency \\
\hline$\Delta f_{ \pm 90^{\circ}}$ & $\pm 90^{\circ}$ bandwidth of the SIW cavity \\
\hline$d_{\mathrm{i}, \mathrm{j}}$ & $\begin{array}{l}\text { Iris opening between the resonators } \mathrm{i} \text { and } \mathrm{j} \\
\text { for } \mathrm{i}, \mathrm{j}=1,2,3, . ., \mathrm{n}\end{array}$ \\
\hline$R$ & $\begin{array}{l}\text { Diameter of the circular hole etched on the } \\
\text { top of the metal layer }\end{array}$ \\
\hline$W_{\mathrm{CPW}}$ & $\begin{array}{l}\text { Width of the conductor backed coplanar } \\
\text { waveguide (CBCPW) transition }\end{array}$ \\
\hline$L_{\mathrm{CPW}}$ & $\begin{array}{l}\text { Length of the conductor backed coplanar } \\
\text { waveguide (CBCPW) transition }\end{array}$ \\
\hline
\end{tabular}

\section{Greek symbols}

$$
\begin{array}{ll}
\varepsilon_{\mathrm{r}} & \text { Relative permittivity } \\
\tan \delta & \text { Loss tangent of the dielectric } \\
\sigma & \text { Conductivity of the tissue }
\end{array}
$$

\section{НОВИ ДИЗАЈН МИНИЈАТУРНИХ СИВ ФИЛТЕРА НА КЕРАМИЧКОМ СУПСТРАТУ ЗА Ц-ПОЈАС}

\section{А. Рхабану, А. Ел Фадл, Н. Џебор, С. Бри}

Приказују се нове структуре и методе дизајнирања минијатурних интегрисаних таласоводних пропусних (СИВ) филтера на керамичком супстрату велике пропустљивости за ц-појас. Циљ је био да се изврши процена изводљивости таквих филтера коришћењем ЕМ симулатора. Таласовод интегрисан у супстрат (СИВ) нуди квалитет и добре електричне перформансе у поређењу са другим планарним техникама. Могућности интегрисања и трошкови израде чине га атрактивним. Керамички материјал има електрична својства погодна за дизајн пасивних уређаја. Велика релативна пропусност са малим диелектричним губицима омогућава израду пасивних компонената у минијатурним димензијама, при чему постоји велика стабилност на високим температурама, што представља значајан критеријум код избора филтера дизајнираног за опрему корисног терета код сателита. Дизајнирана су три СИВ филтера на ТрансТек керамичком супстрату (дебљина $-254 \mu \mathrm{m}, \varepsilon_{\mathrm{r}}-$ $90, \tan \delta-0,0009)$ са прецизним спецификацијама за примену у свемиру. Први филтер је састављен од три СИВ резонатора са директним спајањем, други има три СИВ резонатора са попречним спајањем да би пренос био нула, а трећи има три СИВ резонатора са кружним отворима урезаним на врху металног слоја да би се добио супер-широки појас. Резултати истраживања су приказани, размотрени и упоређени са релевантном литературом. Предложени филтер може да се користи за побољшање перформанси микроталасних уређаја за ц-појас, посебно за сателитску комуникацију. 